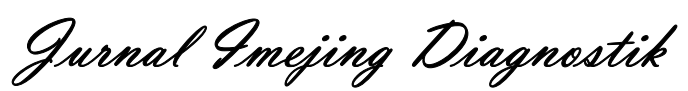

e-ISSN 2621-7457, p-ISSN 2356-301X

\title{
Prosedur Pemeriksaan MRI Leher Pada Kasus Karsinoma Nasofaring Di Instalasi Radiologi Rs Ken Saras Kabupaten Semarang
}

\author{
Yeti Kartikasari ${ }^{1}$, Emi Murniati ${ }^{2}$, Muhammad Sakur ${ }^{3}$ \\ ${ }^{1,2}$ Poltekkes Kemenkes Semarang, Indonesia \\ ${ }^{3}$ Rumah Sakit Paru Ario Wirawan Salatiga, Indonesia \\ Corresponding Author : Yeti Kartikasari \\ e-mail: yeti.kartikasari@gmail.com
}

Received: January $14^{\text {th }}, 2021$; Revised: January $31^{\text {st }}, 2021$; Accepted: February $1^{\text {st }}, 2021$

\begin{abstract}
Background: Magnetic Resonance Imaging (MRI) is a diagnostic imaging modality that can generate slices anatomy body multiplanar by contrast in a very good resolution. The results of the of an MRI description is more accurate for diagnosing Carcinoma of the nasopharynx. On examination of of the neck MRI with the case of carcinoma, after infusion of contrast Moeller and Reif (2003) suggested to use T1 TSE Coronal and axial sequence and using the $4 \mathrm{~mm}$ slice thickness, but in Radiology instalation of Ken Saras Hospital using T1 and T1 TSE TSE Fat Saturation Coronal, sagittal and axial sequence as well as using slice thickness $2 \mathrm{~mm}$ in axial slices. The purpose of this research is to know the procedure of examination of of the neck MRI in the case of Carcinoma of the nasopharynx, justifying T1 Fat Saturation sequence after infusion media kontaras and reasons of wearing slice thickness $2 \mathrm{~mm}$ in axial slices.

Methods: This type of research is qualitative research with case studies approach. Data retrieval is done by observation, documentation, interviews with two specialists in radiology, 2 radiografer and 1 doctor who send the patient. The data obtained analized by using the table categorisation and coding.

Result: The results of the research showed that MRI examination procedure of the neck in the case of Carcinoma of nasopharynx in Radiology Installation of Ken Saras hospital using T1 TSE multi planar (coronal, sagittal and axial), T2 TSE multi planar and T2 TSE Fat Saturation multi planar sequences before infusion of contrast media, T1 and T1 TSE TSE Fat Saturation multi planar sequences after infusion contrast and using the slice thickness $2 \mathrm{~mm}$ in axial slices. Addition sequence T1 TSE Fat Saturation after infusion of contrast aimed to clarify the limits of the tumor with surrounding tissue and image of Lymphadenopathy.

Conclusion: While using $2 \mathrm{~mm}$ slice thickness in axial slices aims to show the abnormalities or nodulessmall nodules on the nasopharynx and to see the expansion Stadium in the surrounding area of the nasopharynx.
\end{abstract}

Keyword : MRI of the neck, Fat Saturation, slice thicknes

\section{Pendahuluan}

Karsinoma nasofaring adalah tumor ganas dengan perilaku klinis, epidemiologi, dan histopatologi yang berbeda dengan karsinoma sel skuamosa pada kepala dan leher. Karsinoma nasofaring menyumbang $0,25 \%$ dari semua keganasan di Amerika Serikat dan 15-18\% keganasan di Cina selatan. Ini juga menyumbang 10-20\% keganasan masa kanak-kanak di Afrika. Rasio laki-laki terhadap perempuan adalah $3: 1$. Hal ini paling umum terjadi pada pasien berusia 40-60 tahun (Razek dan King, 2012). Sering juga ditemukan pada orang yang bukan China di Vietnam, Thailand, Indonesia, Singapura dan Filipina. Kanker nasofaring merupakan salah satu dari kanker terbanyak di Indonesia, berada pada urutan ke-4 kanker terbanyak di Indonesia setelah kanker payudara, kanker leher rahim, dan kanker paru. Di Indonesia, dari seluruh kanker kepala dan leher, kanker nasofaring menunjukkan entitas yang berbeda secara epidemiologi, manifestasi klinis, marker biologi, faktor risiko,

dan faktor prognostik. Prevalensi kanker nasofaring di Indonesia adalah 6.2/100.000, dengan hampir sekitar 13.000 kasus baru, namun itu merupakan bagian kecil yang terdokumentasikan. Kanker nasofaring adalah kanker kepala leher tersering (28.4\%), dengan rasio pria-wanita adalah 2:4 dan endemis di pulau Jawa (Marlinda, 2017).

Sampai saat ini penyebab karsinoma nasofaring belum diketahui pasti. Virus Epstein 
Barr dari penelitian menunjukkan ada hubungan dengan karsinoma nasofaring (Sudiono, 2013).

Metastasis adalah pertumbuhan kanker ke dalam kelenjar limfe dan organ yang berjarak, baik melalui jalur limfogen maupun hematogen. Pembentukan metastasis secara klinis merupakan sifat terpenting dari pertumbuhan kanker karena metastasis ini biasanya tidak dapat ditangani dan sangat menentukan prognosis (Kurniawan dan Yusuf, 2014).

Pada penelitian tentang persentase metastasis jauh pada kanker nasofaring, angka kejadian metastasis pada paru $20 \%$, pada tulang $20 \%$, pada hati $10 \%$, ginjal dan otak masingmasing berkisar $0,4 \%$ dan yang terbanyak adalah metastasis ke kelenjar regional leher. Prognosis secara umum Karsinoma Nasofaring memang tidak baik. Untuk stadium I dilaporkan fiveyears survival rate adalah $83,7 \%$, stadium II $67,9 \%$, stadium III $40,3 \%$, sedangkan pada kasus yang telah terjadi metastasis hanya berkisar 22,3\% (Kurniawan dan Yusuf, 2014).

Magnetic Resonance Imaging (MRI) merupakan salah satu modalitas imaging diagnostik yang dapat menghasilkan irisan anatomi tubuh secara multiplanar dengan kontras resolusi yang sangat baik. MRI dapat menggambarkan strukturstruktur yang kecil tampak lebih baik dan lebih jelas dibandingkan dengan gambaran CT Scan seperti jaringan lunak di hidung dan tenggorokan. Hasil gambaran MRI lebih akurat untuk mendiagnosa karsinoma nasofaring. Dengan MRI dapat mendeteksi suatu sel keganasan misalnya pada nasofaring yang pada saat dilakukan endoskopi tidak terlihat. Sebanyak $82 \%$ kasus karsinoma nasofaring terletak di resessus posterolateral dinding faring (fossa Rossenmuller) dan 12\% lainnya kasus karsinoma nasofaring terletak di bagian tengah, sebanyak 6-10\% dari jumlah kasus karsinoma nasofaring di atas semuanya tidak terdeteksi pada saat pemeriksaan endoskopi namun dapat terdeteksi pada saat dilakukan pemeriksaan MRI. MRI juga bisa digunakan untuk mendeteksi tingkat tumor, termasuk penyebaran perineural dan perluasan tumor intrakranial (Razek dan King, 2012).

Fat Saturation umumnya dikenal sebagai Chemical Saturation. Teknik ini mengambil keuntungan dari perbedaan frekuensi resonansi antara air dan lemak dan hanya mengeksitasi proton lemak saja. Fat Saturation merupakan teknik yang menggunakan chemichal shift selective $R F$ Saturation pulse $90^{\circ}$ yang diaplikasikan pada lipid peak yang diikuti spoiler gradien pulse. (Cameron, 2009). Teknik ini didasarkan pada chemical shift
(3,4 ppm) yang merupakan perbedaan dalam frekuensi resonansi antara proton lemak dan air. Aplikasi dari frekuensi yang sempit dengan pemilihan pulsa mengeksitasi sebagian besar proton-proton lemak. Magnetisasi tranversal dihilangkan setelahnya oleh spoiler Gradiens., sehingga tidak ada magnetisasi lemak pada gambar (Klefer, 2011).

Slice thickness adalah tingkat ketebalan irisan/potongan. Besarnya slice thickness akan mempengaruhi spatial resolusi gambar yang dihasilkan. Slice thickness yang tipis akan menghasilkan resolusi yang baik, namun pada besar FOV yang sama akan membutuhkan waktu akuisisi data yang lebih lama (Westbrook dan Kaut, 2011).

Pada pemeriksaan MRI leher, Moeller dan Reif (2003) menyarankan untuk menggunakan sekuens coronal T2 weighted fat saturation, axial $\mathrm{T} 2$ weighted, axial $\mathrm{T} 1$ weighted, sagital $\mathrm{T} 2$ weighted dan untuk post injeksi media kontras gadolinium axial $\mathrm{T} 1$ weighted dan coronal $\mathrm{T} 1$ weighted. Sedangkan menurut Razek dan King (2012), protokol rutin MRI leher pada kasus karsinoma nasofaring adalah $\mathrm{T} 1$ weighted pada potongan axial dan sagital, T2 Turbo Spin Echo (TSE) potongan axial dan post kontras gadolinium $\mathrm{T} 1$ weighted (dengan dan tanpa fat saturation) potongan axial dan coronal.

Menurut Razek dan King (2012), Tebal irisan/ slice thickness pada pemeriksaan MRI Nasofaring pada kasus karsinoma adalah 3-5 mm, sedangkan menurut Moeller dan Reif (2003), slice thickness pada pemeriksaan MRI leher pada kasus karsinoma adalah $4 \mathrm{~mm}$.

Selama melaksanakan Praktek Kerja Lapangan (PKL) di Rumah Sakit Ken Saras Semarang, penulis menjumpai pemeriksaan MRI leher pada kasus karsinoma Nasofaring. Pemeriksaan ini menggunakan Sekuens yang berbeda dengan teori yang ada. Sekuens yang diambil pada pemeriksaan tersebut yaitu, potongan coronal T1 TSE, T2 TSE, dan T2 TSE fat saturation, potongan sagital T1 TSE, T2 TSE, dan T2 TSE fat saturation dan potongan axial T1 TSE, T2 TSE, dan T2 TSE fat saturation, kemudian dilanjutkan injeksi media kontras. Sekuens yang digunakan pada pemeriksaan post kontras adalah T1 TSE Coronal, Sagital dan axial serta di tambah Sekuens T1 TSE fat saturation coronal, sagital, dan axial. Selain itu tebal irisan yang digunakan pada pemeriksaan MRI leher pada kasus karsinoma Nasofaring juga berbeda dengan teori yang ada. Slice thickness yang di gunakan untuk pemeriksaan MRI leher pada kasus karsinoma Nasofaring di RS Ken Saras Kabupaten Semarang adalah 2 mm untuk 
irisan axial dan $3 \mathrm{~mm}$ untuk irisan coronal dan sagital.

Tujuan Penelitian ini untuk menjelaskan prosedur pemeriksaan MRI Leher pada kasus karsinoma nasofaring di Instalasi Radiologi Rumah Sakit Ken Saras Kabupaten Semarang, mengetahui alasan pemeriksaan MRI Leher pada kasus karsinoma Nasofaring di Instalasi Radiologi Rumah Sakit Ken Saras Kabupaten Semarang menggunakan penambahan sekuen T1 TSE fat saturation setelah pemberian media kontras. 2 .

\section{Metode}

Jenis penelitian ini adalah kualitatif dengan pendekatan studi kasus. Pengambilan data dilakukan pada bulan Desember 2017 dan dilanjutkan dengan pada bulan April sampai dengan Mei 2018 di Unit Radiologi Rumah Sakit Ken Sałas Kabupaten Semarang dengan metode observasi, wawancara, studi dokemuntasi dengan Subyàk dalam penelitian ini adalah 1 pasien dengan permintaan MRI Leher dengan kasus karsinonna Nasofaring, 2 radiografer yang mengerjakan MRI, 2 dokter spesialis radiologi yang sudah mengerjakan/membaca hasil MRI cukup lama dan 1 dokter pengirim. Data yang diperoleh dari penelitian dianalisis dengan interaktif model, membuat transkrip wawancara kemudian direduksi dan diolah dalam bentuk koding terbuka, disajikan dalam bentuk kuotasi dan kemudian dapat diambjil kesimpulan.

\section{Hasil dan Pembahasan}

\section{Paparan Kasus}

Berdasarkan observasi penulis, pasien 1 atas nama Tn. Ry ini merupakan pasien rawat jalan ka)ri poli radioterapi. Pasien datang ke instalasi radiologi pada tanggal 6 Desember 2017 untuk dilakukan pemeriksaan MRI Leher. Pasien sudah di lakuløąn kemoterapi 6 kali, pasien mengeluh tangan kanan dan kiri kesemutan. Dokter menyarankan untuk dilakukan Pemeriksaan MRI Leher unttol mengetahui perkembangan massa di nasofaring setelah di lakukan kemoterapi sebanyak 6 kali.

Pasien 2 atas nama Ny. C ini merupalanin pasien rawat jalan dari poli radioterapi. Pasien datang ke instalasi radiologi pada tanggal 11 Desember 2017 untuk dilakukan pemeriksaan MRI Leher. Pasien sudah di lakukan kemoterapi 7 kali, pasien mengeluh penglihatan mata kiri dan pendengaran telinga kiri berkurang. Dokter menyarankan untuk dilakukan Pemeriksaan MRI Leher untuk mengetahui perkembangan massa di nasofaring setelah di lakukan kemoterapi sebanyak 6 kali.
Pasien 3 atas nama Ny. S ini merupakan pasien rawat jalan dari poli radioterapi. Pasien datang ke instalasi radiologi pada tanggal 11 Desember 2017 untuk dilakukan pemeriksaan MRI Leher. Pasien mengeluh lehernya sakit jika di gerakan kurang lebih selama 1 tahun, terdapat benjolan di samping kanan dan kiri leher. Dokter menyarankan untuk dilakukan Pemeriksaan MRI Leher untuk menegakkan diagnosa penyakit yang dialami Ny. S.

Prosedur Pemeriksaan MRI Leher dengan kasus karsinona nasofaring di Instalasi Radiologi Rumah Sakit Ken Saras Kabupaten Semarang.

Persiapan Pasien

Pasien puasa makan 4-5 jam sebelum pemeriksaan dimula

Pasien cek laboratorium ureum dan creatinin

Pasien tidak mengkonsumsi metformin 2x24 jam sebelum dan sesudah pemeriksaan MRI

Pasien atau keluarga mengisi formulir inform consent yang disediakan

Petugas melakukan screening terhadap pasien dengan daftar pertanyaan (memastikan apakah pasien memakai alat pacu jantung/peacemaker, kli/koil di pembulu darah,katup jantung buatan/ artivicial heart velve, filter/stent pada pembuluh darah, Pemasangan alat logam dalam tubuh/implant prothesis, lain-lain seperti susuk, bulu mata, tatto $\mathrm{dsb})$

Selama pemeriksaan di ruang MRI pasien tidak diperkenankan membawa/memakai benda yang mengandung logam (Kartu kredit, ATM, arloji, handphone, kacamata, pisau, kawat gigi dsb)

Pasien kemudian dipersilahkan untuk mengganti pakaian dengan menggunakan baju pasien

Sebelum pemeriksaan dimulai pasien diminta untuk buang air kecil terlebih dahulu (agar nyaman selama pemeriksaan berlangsung)

Setelah selesai menggunakan baju pasien, pasien di timbang berat badannya untuk menyesuaikan jumlah media kontras yang akan digunakan

Pasien di screnning kembali menggunakan metal detektor untuk memastikan kembali bahwa sudah tidak ada logam yang menempel pada tubuh pasien Pasien masuk kedalam ruang MRI, kemudian dijelaskan kembali tentang prosedur pemeriksaan

Persiapan alat dan bahan

1) Pesawat MRI 


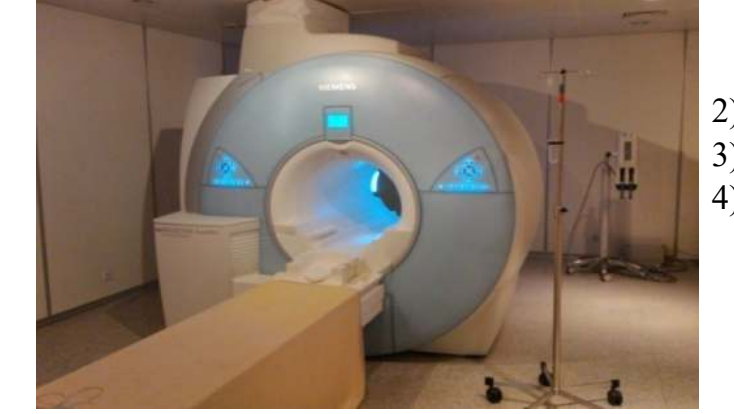

Gambar 1. Pesawat MRI

2) Head matrix coil and neck matrix coil

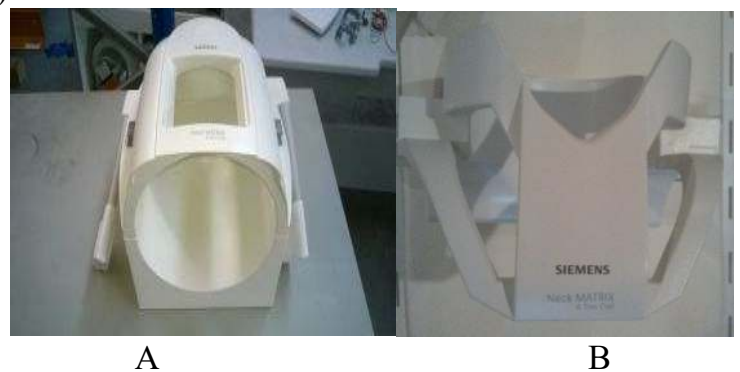

Gambar 2. A. Head Matrix Coil B. Neck Matrix Coil

3) Headphone

4) Sponge/ busa untuk fiksasi

5) Tombol emergency

6) Selimut

7) Spuit $10 \mathrm{cc}$

8) Media Kontras Gadolinium

9) Abocath No 22

10) Printer Kodak Dry View 5850

11) Metal Detector

12) $\quad C C T V$

13) Ear plug

b. Petunjuk Teknis

1) Pasien datang ke radiologi sesuai dengan perjanjian yang telah dilakukan sebelumilyt dan telah melakukan persiapan

2) Pasien mengganti baju dengan baju khusus pasien yang telah disediakan pihak radiologig.

c. Teknik pemeriksaan MRI Leher pada kasus karsinoma Nasofaring di Instalasi Radiolpgi Rumah Sakit Ken Saras Kabupaten Semarang

1) Posisi Pasien

Pasien supine, head first di m(j)a pemeriksaan. Kedua tangan rileks berada disamplkg tubuh. Sebelum pemeriksaan dilakukan pasien diberi penjelasan kembali tentang proses yang akan dilalui selama pemeriksaan. Diberi penjelasan tentang tombol emergency dan diberikan headphone. Setelah pasien sudah mengerti jalannya pemeriksaan, kemudian dilakukan pemasangan head matrix coil dan neck coil. pasien diposisikan tepat pada garis central point berada pada pertengahan leher. Scan area dari sinus frontalis sampai dengan infra clavikula. Lampu kolimator dimatikan kemudian pasien di masukkan ke dalam bore magnet.

Teknik Pengambilan Gambar

Registrasi Data Pasien

Localizer

Setelah pengaturan posisi pasien kemudian lakukan registrasi pasien pada komputer kemudian pilih parameter-parameter untuk MRI Leher apabila pasien tersebut sudah pernah MRI Leher sekuensnya bisa disamakan dengan MRI nasofaring yang sebelumnya, hal ini di maksudkan agar dapat di ketahui perkembangan tumor dari hasil MRI yang pertama dengan hasil MRI berikutnya . Selanjutnya lakukan scanning untuk mendapatkan localizer sagital, coronal, dan Sagital

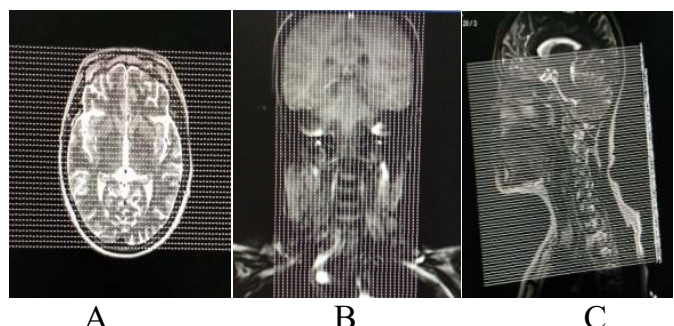

Gambar 3. Localizer, A. Potongan Axial, B. Potongan Coronal, C. Potongan Sagital

Pulse sekuens yang digunakan sebelum kontras

Sekuen yang di gunakan pada pemeriksaan MRI Leher pada kasus karsinoma Nasofaring di Instalasi Radiologi Rumah Sakit Ken Saras Kabupaten Semarang adalah sebelum pemasukan media kontras adalah : Coronal (T2 TSE, T2 TSE Fat Saturation dan T1 TSE), Sagital (T2 TSE, T2 TSE Fat Saturation dan T1 TSE) dan Axial (T2 TSE, T2 TSE Fat Saturation dan T1 TSE). Scanning Coronal T2 TSE

$\begin{array}{ll}\text { Localize } & \text { : Sagital } \\ \text { TR } & : 8500 \mathrm{~ms} \\ \text { TE } & : 94 \mathrm{~ms}\end{array}$

Slice Thickness $: 3,0 \mathrm{~mm}$

Slice Gap : : 1,35

FOV : $360 \mathrm{~mm}$

Matrix : $157 \times 384$

Bandwitdth $: 191$

Flip Angle : : 90

Scan time $\quad: 04.07$

Scan area $\quad$ : Sinus frontalis-infra clavikula

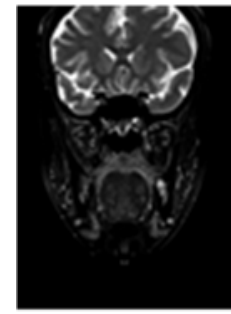

A

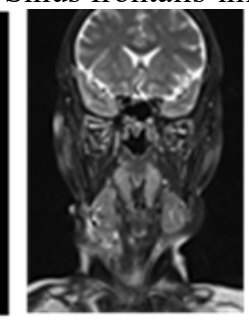

B

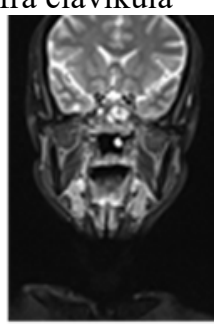

C
Gambar 4. Slice 20 (sejajar MAE) T2TSE potongan koronal, A. Pasien 1, B. Pasien 2, C. Pasien 3 
(2) Scanning Coronal T1 TSE

$\begin{array}{lll}\text { (a) } & \text { Localize } & \text { : Sagital } \\ \text { (b) } & \text { TR } & : 883 \mathrm{~ms} \\ \text { (c) } & \text { TE } & : 10 \mathrm{~ms} \\ \text { (d) } & \text { Slice Thickness } & : 3,00 \mathrm{~mm} \\ \text { (e) } & \text { Slice Gap } & : 1,35 \\ \text { (f) } & \text { FOV } & : 360 \mathrm{~mm} \\ \text { (g) } & \text { Matrix } & : 158 \times 384 \\ \text { (h) } & \text { Bandwidth } & : 170 \\ \text { (i) } & \text { Flip angle } & : 90 \\ \text { (j) } & \text { Scan time } & : 03.10 \\ \text { (k) } & \text { Scan area } & : \text { sinus frontalis-infra } \\ & \text { clavikula } & \end{array}$

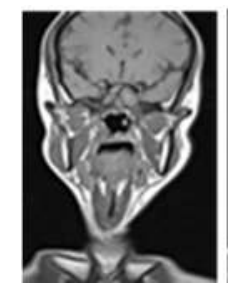

A

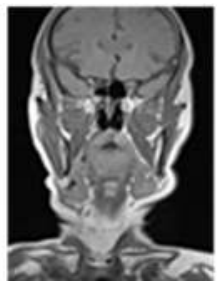

$\mathrm{B}$

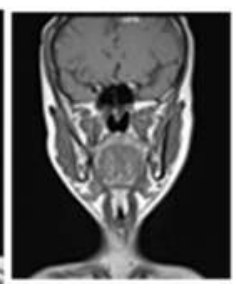

$\mathrm{C}$
(5)

(a)

(b)

(c)

(d)

(e) (f) (g)

Gambar 5. Slice 20 (sejajar MAE) T2 TSE (h) potongan koronal, A. Pasien 1, B. Pasien 2, C. Pasieniiß

(3) Scanning Coronal T2 TSE Fat Saturation (j)
(a) Localize
: Sagital
(b) TR
$: 11780 \mathrm{~ms}$
(c) $\mathrm{TE}$
$: 81 \mathrm{~ms}$
(d) Slice Thickness : $3,0 \mathrm{~mm}$
(e) Slice Gap
(f) FOV
$: 1,35$
(g) Matrix
(h) Bandwitdth
(i) Flip Angle
(j) Scan time
(k) Scan area
: $360 \mathrm{~mm}$
: $158 \times 320$
$: 191$
$: 90$
: 03:37
:Sinus clavikula

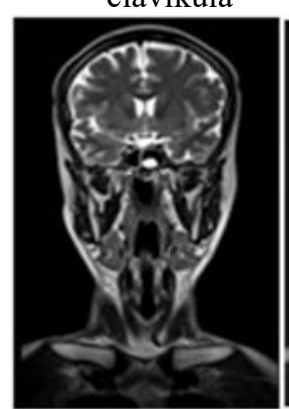

A

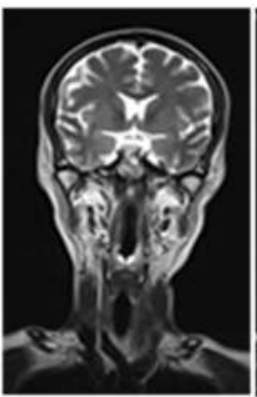

$\mathrm{B}$ frontalis-infra (j)

(k)

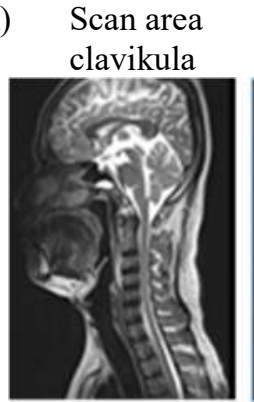

A
: 05.58

:Sinus

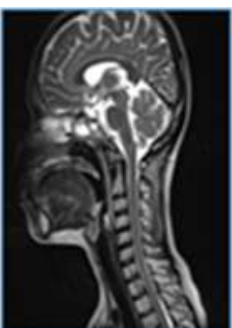

B frontalis-infra

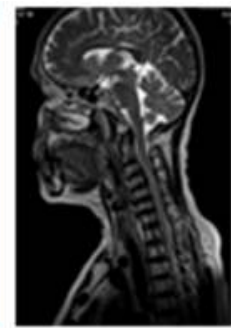

C

Gambar 7. Slice 20 (sejajar hidung) T2 TSE potongan sagital, A. Pasien 1, B. Pasien 2, C. Pasien 3

Scanning Sagital T1 TSE

Localize

: coronal

TR

TE

: $1320 \mathrm{~ms}$

Slice Gap

FOV

: 3,0 $\mathrm{mm}$

Matrix

$$
: 420 \mathrm{~mm}
$$

$: 1,58$

Bandwitdth

Flip Angle

Scan time

$: 216 \times 320$

Scan area clavikula

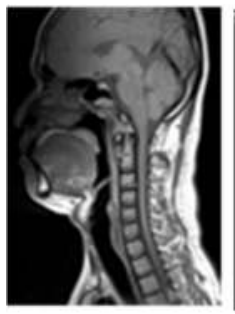

A

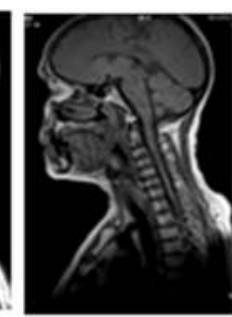

B
$: 90$

: 02.52

: $\quad$ Sinus frontalis-infra

Gambar 8. Slice 20 (sejajar hidung) T1 TSE potongan sagital, A. Pasien 1, B. Pasien 2, C. Pasien 3

Scanning Sagital T2 TSE Fat Saturation
(a) Localize
: coronal
(b) TR
: $8840 \mathrm{~ms}$
(c) TE
$: 81 \mathrm{~ms}$
(d) Slice Thickness : $3,0 \mathrm{~mm}$
(e) Slice Gap : : 1,58
(f) FOV : $370 \mathrm{~mm}$
(g) Matrix : $173 \times 320$
(h) Bandwitdth : 191
(i) Flip Angle : :90

(j) Scan time : 02.52

(k) Scan area $\quad:$ Sinus frontalis-infra koronal, A. Pasien 1, B. Pasien 2, C. Pasien 3

$\begin{array}{lll}\text { (4) } & \text { Scanning Sagital T2 TSE } \\ \text { (a) } & \text { Localize } & \text { : coronal } \\ \text { (b) } & \text { TR } & : 15533 \mathrm{~ms} \\ \text { (c) } & \text { TE } & : 91 \mathrm{~ms} \\ \text { (d) } & \text { Slice Thickness } & : 3,0 \mathrm{~mm} \\ \text { (e) } & \text { Slice Gap } & : 1,58 \\ \text { (f) } & \text { FOV } & : 420 \mathrm{~mm} \\ \text { (g) } & \text { Matrix } & : 157 \times 384 \\ \text { (h) } & \text { Bandwitdth } & : 191 \\ \text { (i) } & \text { Flip Angle } & : 90\end{array}$

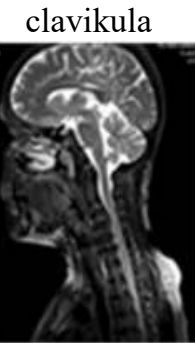

A

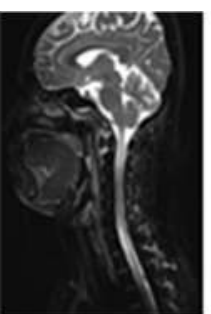

B

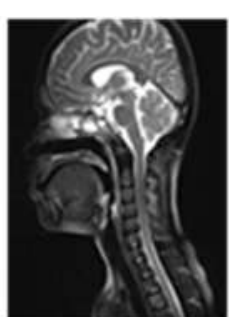

C 
Gambar 9. Slice 20 (sejajar hidung) T2 TSE Fat Saturation potongan sagital, A. Pasien 1, B. Pasien 2, C. Pasien 3

(7) Scanning Axial T1 TSE
(a) Localize
: Sagital
(b) TR
: $2960 \mathrm{~ms}$
(c) TE
: $11 \mathrm{~ms}$
(d) Slice Thickness
: $2,0 \mathrm{~mm}$
(e) Slice Gap
$: 1,65$
(f) FOV
: $420 \mathrm{~mm}$
(g) Matrix
(h) Bandwitdth
: $158 \times 384$
(i) Flip Angle
(j) Scan time
(k) Scan area clavikula

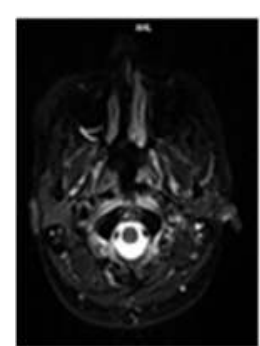

A

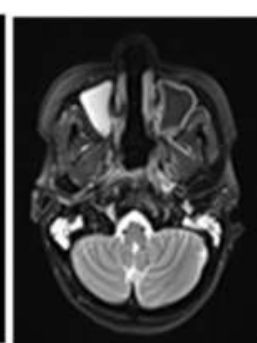

B

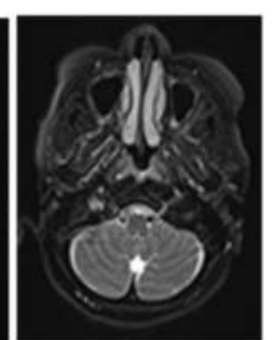

$\mathrm{C}$
Gambar 10 . Slice 22 (setinggi hidung) T1 TSE potongan Axial, A. Pasien 1, B. Pasien 2, C. Pasien 3

(8) Scanning Axial T2 TSE

$\begin{array}{llll}\text { (a) } & \text { Localize } & \text { : Sagital } & \\ \text { (b) } & \text { TR } & : 10750 \mathrm{~ms} & \\ \text { (c) } & \text { TE } & : 76 \mathrm{~ms} & \\ \text { (d) } & \text { Slice Thickness } & : 2,0 \mathrm{~mm} & \\ \text { (e) } & \text { Slice Gap } & : 1,65 \\ \text { (f) } & \text { FOV } & : 390 \mathrm{~mm} & \\ \text { (g) } & \text { Matrix } & : 158 \times 320 & \\ \text { (h) } & \text { Bandwitdth } & : 191 \\ \text { (i) } & \text { Flip Angle } & : 90 & \\ \text { (j) } & \text { Scan time } & : 04: 46 & \text { frontalis-infra } \\ \text { (k) } & \text { Scan area } & : \text { Sinus } & \\ & \text { clavikula } & & \end{array}$

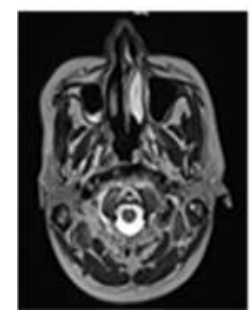

A

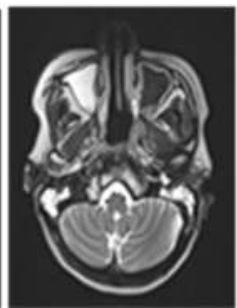

B

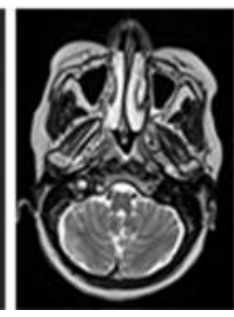

$\mathrm{C}$
Gambar 11. Slice 22 (setinggi hidung) T2 TSE potongan Axial, A. Pasien 1, B. Pasien 2, C. Pasien 3

(9) Scanning Axial T2 TSE Fat Saturation
(a) Localize
: sagital
(b) TR
: $10750 \mathrm{~ms}$
(c) $\mathrm{TE}$
: $86 \mathrm{~ms}$
(d) Slice Thickness
: $2,0 \mathrm{~mm}$
(e) Slice Gap
$: 1,65$
(f) FOV
: $390 \mathrm{~mm}$

$\begin{array}{llll}\text { (g) } & \text { Matrix } & : 158 \times 320 & \\ \text { (h) } & \text { Bandwitdth } & : 191 & \\ \text { (i) } & \text { Flip Angle } & : 90 \\ \text { (j) } & \text { Scan time } & : 05: 46 & \\ \text { (k) } & \begin{array}{l}\text { Scan area } \\ \text { clavikula }\end{array} & \text { :sinus frontalis }- \text { infra }\end{array}$

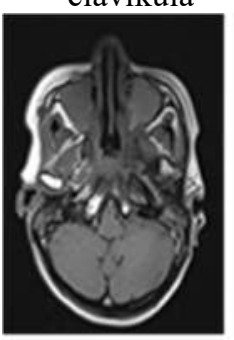

A

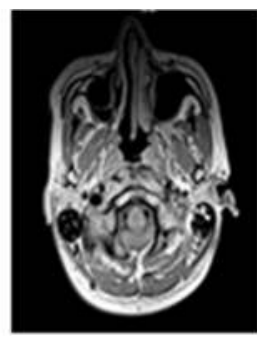

B

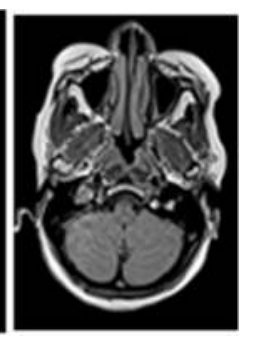

C
Gambar 12. Slice 22 (setinggi hidung) T2 TSE Fat Saturation potongan Axial, A. Pasien 1, B. Pasien 2,C. Pasien 3

b) Setelah scanning prekontras selesai dilakukan persiapan untuk pemeriksaan menggunakan media kontras Gadolinium. Pada pemeriksaan ini, konsentrasi media kontras yang digunakan adalah $0,5 \mathrm{mmol} / \mathrm{mL}$. Perhitungan volume media kontras yang digunakan adalah 0,2 mL media kontras Gadolinium, dikalikan dengan berat badan pasien. Untuk pasien 1 volume kontras yang di gunakan adalah $0,2 \mathrm{~mL}$ × $50=10 \mathrm{~mL}$, pasien 2 menggunakan media kontras $9,4 \mathrm{~mL}$ dan pasien 3 menggunakan media kontras 8,6 mL. Media kontras dimasukkan oleh perawat secara bolus injeksi intra vena menggunakan abocath ukuran 22.

c) Kemudian dilanjutkan scanning dengan protokol sekuens post kontras sebagai berikut:Coronal T1 dan T1 TSE Fat Saturation, Sagital T1 dan T1 TSE Fat Saturation, Axial T1 dan T1 TSE Fat Saturation, dengan menggunakan parameter Scanning yang sama dengan parameter scanning pre kontras.

d) Setelah pemeriksaan selesai, pasien di keluarkan dari Bore magnet dan disuruh ganti baju

d. Filming

Setelah proses scanning selesai, gambar hasil scanning kemudian di email ke radiolog. Pencetakan film dilakukan setelah ada hasil bacaan dari radiolog. Mengingat gambar yang dihasilkan dari MRI leher pada kasus karsinoma nasofaring ini cukup banyak, maka citra yang dipilih harus benarbenar memiliki kemampuan untuk menegakkan diagnosa yang tinggi. Biasanya film yang di cetak sebanyak 3 lembar tergantung dari dokter radiolognya.

e. Hasil Ekspertise 


\section{1) Pasien 1}

Tampak penebalan nasofaring kiri yang tampak enhance pada $\mathrm{T} 1+\mathrm{C}$

Nasofaring kanan baik

Tampak kesuraman hiperintens pada T2 di mastoid air cell kiri

Tak tampak enhancementpatologis pada parenkim atas yang tervisualisasi

Sela dan paracela baik, tak tampak enhancement patologis

Tampak limfadenopati di regio colli level 4,5 kanan kiri

Tampak kesuraman hiperintens pada sinus spenoid kiri

Orofaring dan laring tenang

Kesan:

Massa enhance di nasofaring kiri yang meluas ke parafangeal kiri

Limfadenopati di regio colli kanan kiri

Mastoiditis kiri

Sphenoiditis kiri minimalis

\section{2) Pasien 2}

Perbandingan dengan MRI nasofaring kontras tanggal 16 Agustus 2017

Masih tampak enhancing mass di nasofaring kanan.Dibandingkan MRI sebelumnya ukuran massa jelas mengecil.

Fossa rossenmuller kanan obliterasi kiri terbuka.

Torus tubarius kanan kiri tumpul.

Tak tampak massa tumor di retrofaring, orofaring, hipofaring, cavum nasi, sinus paranasal dan infratemporal.

Tak tampak massa tumor di parafaring space masticalor space dan buccal space kanan kiri.Tak tampak massa tumor di orbita dan intracranial.

Tak tampak limfonodi di region colli kanan kiri.

Tak tampak nodul di vertebra cervico-thoracal.

Masih tampak pansinusitis dan mastoiditis bilateral, tampak sama dibanding imaging sebelumnya.

Kesan

Enhancing mass di nasofaring kanan tampak lebih kecil

Tak tampak limfonodi regio colli kanan kiri.

Pansinusitis dan mastoiditis bilateral stq.

\section{3) Pasien 3}

Tampak enhancing mass di nasofaring kanan kiri dan retrofaring.

Fossa Rossenmuller kanan kiri obliterasi.

Torus tubarius kanan kiri tumpul.

Tak tampak enhancing mass di parafaring space masticator space dan buccal space kanan kiri.

Tak tampak enhancing mass di orofang, hipofaring, cavum nasi, sinus paranasalis dan infratemporal.

Tampak enhancing nodul di carolid space kanan kiri.
Tak tampak massa tumor di orbita dan intracranial. Tampak limfadenopali metastasis di regio colli kanan kiri level 1B sampai 5, ukuran terbesar $3,5 \times 18 \mathrm{~cm}$.

Tak tampak nodul di vertebra cervico-thoracal.

Tampak penebalan mukosa hiperintens di sinus maksilaris kiri.

3. Alasan Pemeriksaan MRI Leher Pada Kasus Karsinoma Nasofaring di Instalasi Radiologi Ken Saras Kabupaten Semarang menggunakan penambahan sekuen T1 TSE Fat Saturation setelah pemberian media kontras

Pemeriksaan MRI Leher pada kasus karsinoma nasofaring di Instalasi Radiologi Rumah Sakit Ken Saras Semaran menggunakan 15 sekuen yaitu : T1 TSE multi planar (koronal, axial dan sagital),T2 TSE multi planar, T2 TSE Fat Saturation multi planar dan setelah pemasukan media kontras menggunakan sekuen T1 TSE multi planar di tambah sekuen T1 TSE Fat Saturation multi planar. Alasan penambahan sekuen T1 TSE Fat Saturation ini adalah untuk memperjelas batas massa dengan jaringan di sekitarnya. Dengan ditambahkannya Fat Sat batas massa dengan daerah sekitarnya lebih tegas. Gambaran massa setelah pemberian kontras akan tampak hiper intens, sedangkan lemak gambaranya juga hiper intens. Karena daerah nasofaring juga banyak dikelilingi dengan lemak maka pemberian Fat Sat ini berguna untuk menekan lemak disekitarnya sehingga gambaran lemak akan tampak hitam dan gambaran media kontras yang diserap oleh massa diharapkan akan lebih enhance.

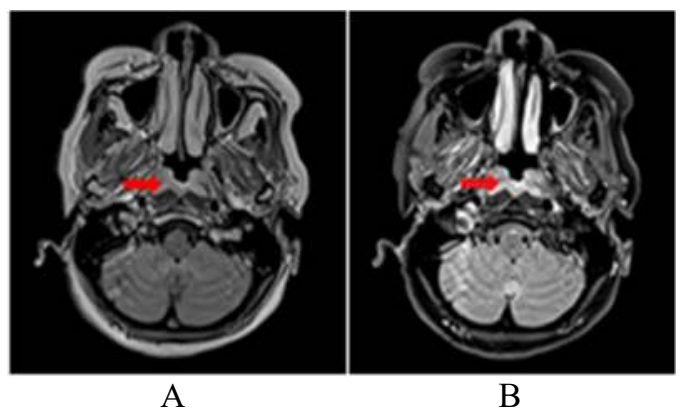

kontras, B. T1 TSE Fat Saturation Post kontras

Pada gambar 4. 25 dapat dilihat gambaran karsinoma nasofaring pada gambar B (sekuen T1 TSE Fat Saturation Post kontras), terlihat lebih hiperintens dan batas dengan jaringan sekitarnya juga lebih jelas jika di bandingkan dengan gambar A (T1 TSE Post kontras).

Selain itu dengan penambahan sekuen T1 TSE Fat Saturation setelah pemasukan media kontras juga akan memperjelas jika ada gambaran limfadenopati. Kelenjar limfa yang normal pada 
sekuen T1 Fat Saturation tidak akan kelihatan karena tersupresi, tapi limfadinopati yang malignen atau patologis akan tampak lebih enhance.

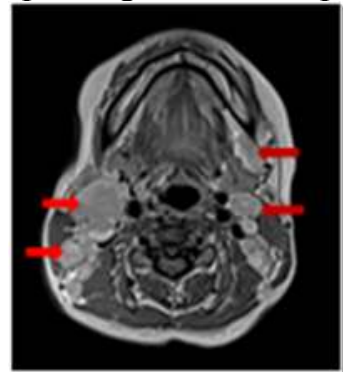

A

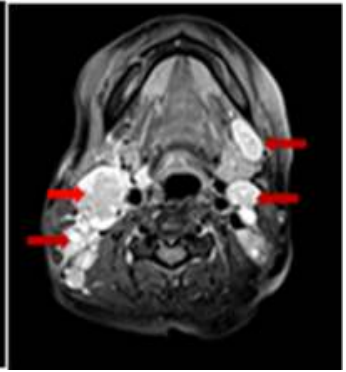

B
B. T1 TSE Fat Saturation Post kontras

Pada gambar 4. 26 dapat dilihat gambaran limfadenopati pada gambar B (T1 TSE Fat Saturation Post kontras) terlihat lebih hiperintens jika di bandingkan dengan gambar A (T1 TSE Post kontras).

4. Alasan pemeriksaan MRI Leher pada kasus karsinoma nasofaring di Instalasi Radiologi Rumah Sakit Ken Saras Kabupaten

Semarang pada irisan axial menggunakan slice thickness $2 \mathrm{~mm}$.

Pemeriksaan MRI Leher pada kasus karsinoma nasofaring di Instalasi Radiologi Rumah Sakit Ken Saras Semarang menggunakan menggunakan tebal irisan $2 \mathrm{~mm}$ pada irisan axial. Hal ini disebabkan karena organ-organ di nasofaring itu kecil-kecil, sehingga di harapkan dengan penggunaan tebal irisan yang tipis tidak ada kelainan yang terlewatkan. Selain itu penggunaan tebal irisan $2 \mathrm{~mm}$ pada irisan axial juga bermanfaat untuk melihat perluasan stadium di daerah sekitar nasofaring. Di sekitar nasofaring terdapat musculus-musculus regio colli yang kecil-kecil sehingga di perlukan irisan yang tipis untuk bisa menampakan gambaran musculus-musculus tersebut. Penggunaan tebal irisan $2 \mathrm{~mm}$ juga bermanfaat untuk menilai vaskuler-vaskuler di sekitar nasofaring. Di sekitar nasofaring terdapat banyak vaskuler-vaskuler, yang paling kelihatan jelas adalah arteri carotis. Percabangan dari arteri carotis ini kecil-kecil dan akan tampak lebih jelas pada irian yang tipis. Pada pemeriksaan MRI leher pada kasus karsinoma nasofaring, pemerikksaan vaskuler ini sangat penting untuk penentuan stadium dari massa, karena jika ada vaskuler yang terlingkup atau tertutup massa maka itu sudah menaikan stadium dari massa tersebut.

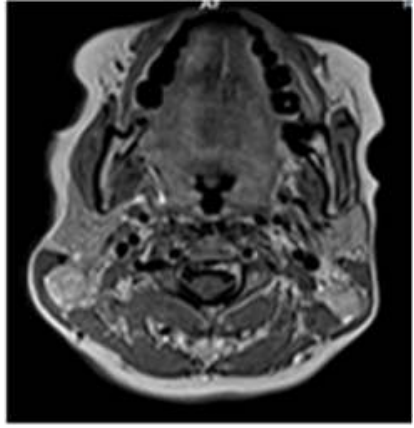

Gambar 15. Vaskuler-vaskuler kecil percabangan dari arteri carotis pada potongan T1 TSE post kontras axial dengan tebal irisan $2 \mathrm{~mm}$

Pada gambar 4. 27 dapat dilihat, gambaran vaskuler yang kecil-kecil (percabangan arteri carotis) dapat di tampakkan dengan detail yang baik dengan menggunakan slice thicness $2 \mathrm{~mm}$.

Prosedur pemeriksaan MRI Leher pada Kasus Karsinoma Nasofaring di Instalasi Radiologi Rumah Sakit Ken Saras Kabupaten Semarang

Persiapan Alat

1) Pesawat MRI MRI yang digunakan yaitu 1,5 Tesla,yang mengunakan magnet Super Konduktor. Medan magnet dibangkitkan dengan memberikan arus listrik pada kumparan. Kuat medan magnet yang mampu dihasilkan mencapai 1,5 Tesla. Karakteristiknya adalah tahanan penghantar nol, arus listrik kontinyu, medan magnet konstan, membutuhkan pendingin (helium) dan stabilitas medan magnet tinggi serta homogen.

2) Peralatan Pendukung yaitu penutup telinga (headphone) sehingga dapat membantu mengurangi suara bising yang diterima oleh pasien selama pemeriksaan berlangsung. Juga terdapat CCTV untuk monitoring keadaan pasien. Menurut Nurul dan Dwi (2017) fungsi utama headphone pada pemeriksaan MRI adalah untuk kenyamanan pasien dan untuk melindungi organ pendengaran dari suara bising yang di timbulkan oleh mesin MRI.

Menurut penulis, headphone yang ada di instalasi radiologi rumah sakit Ken Saras terlalu besar, karena kadang ada pasien yg tidak mau memakai penutup telinga karena merasa kesakitan waktu memakai headphone. Hal ini disebabkan karena headphone tertekan oleh koil sehingga headphone menekan telinga pasien dengan keras.

Sarannya penutup telinga (headphone) agar di ganti yang lebih kecil atau tipis sehingga tidak tertekan oleh coil yang menyebabkan pasien kurang nyaman sehingga dapat menimbulkan gambaran artefak yang diakibatkan pergerakan pasien (motion artefact).

3)

Persiapan Pasien

Secara umum persiapan pemeriksaan MRI nasofaring apabila tidak menggunakan media kontras tidak ada persiapan khusus seperti puasa atau persiapan khusus lainnya. Tetapi apabila pemeriksaan MRI nasofaring menggunakan media kontras maka pasien 
diminta untuk puasa makan 4-5 jam sebelum pemeriksaan dilakukan serta cek laboratorium untuk ureum dan creatin.

Sebelum dilakukan scanning, pasien atau keluarga pasien diminta untuk mengisi informed consent sebagai persetujuan tindakan MRI Leher dengan pemberian media kontras Gadolinium, evaluasi screening yang berisi tentang persetujuan akan dilakukan pemeriksaan dan screening mengenai keadaan pasien apakah pasien sedang memakai stent, pace maker atau benda-benda logam yang dapat menimbulkan artefak. serta penjelasan singkat mengenai tata laksana pemeriksaan secara lisan dan tidak diperbolehkan untuk banyak bergerak selama pemeriksaan.

Menurut penulis persiapan pasien untuk pemeriksaan MRI Leher pada kasus karsinoma nasofaring di instalasi Radiologi Rumah Sakit Ken Saras sudah sesuai dengan protap, tapi menurut penulis sebaiknya instruksi-instruksi yang menyangkut persiapan pemeriksaan harus dijelaskan tidak hanya kepada pasien tetapi juga kepada keluarga pasien yang ikut menemani pasien. Serta di berikan kertas catatan yang berisi ketika mau pemeriksaan MRI harus membawa hasil laboratorium ureum dan creatinin, agar pasien ketika datang ke radiologi sudah benar-benar siap untuk dilaksanakan pemeriksaan sehingga tidak menggangu jadwal pemeriksaan radiologi. Karena sering kali pasien datang ke Radiologi belum cek ureum dan creatinin sehingga menggangu jadwal pemeriksaan MRI.

\section{b. Scanning Protokol}

1) Posisi Pasien: Pasien supine, head first di meja pemeriksaan. Kedua tangan rileks berada disamping tubuh. Sebelum pemeriksaan dilakukan pasien diberi penjelasan kembali tentang proses yang akan dilalui selama pemeriksaan. Diberi penjelasan tentang tombol emergency dan diberikan headphone. Setelah pasien sudah mengerti jalannya pemeriksaan, kemudian dilakukan pemasangan head matrix coil dan neck coil. pasien diposisikan tepat pada garis central point berada pada pertengahan leher. Lampu kolimator dimatikan kemudian pasien di masukkan ke dalam bore magnet.

2) Mengatur parameter scanning

3) Planning Scanning

Setelah mendapatkan localizer sagital, transversal, dan coronal maka dilanjutkan dengan membuat planning scanning. Jika akan membuat potongan coronal maka ambil localizer dari sagital (dengan sudut kemiringan mengikuti batang otak) dan localizer transversal dengan FOV mengikuti arah kedua orbita agar gambaran simetris. Untuk membuat potongan sagital melihat dari localizer coronal (tegak lurus dengan sphenoid, garis tengah FOV pada pertengahan cervical). Sedangkan untuk membuat potongan axial lihat dari localizer sagital (sejajar dengan pallatum) dan lihat dari localizer coronal (sejajar dengan os sphenoid). Biasanya untuk kasus evaluasi post terapi FOV nya mencakup daerah head minimal sinus frontalis harus tercover dan neck juga harus tercover. Pastikan tidak ada yang terpotong daerah atas dan bawahnya serta kanan dan kirinya, kemiringan garis FOV mengikuti objeknya agar didapatkan hasil yang simetris.

4) Sekuen dan Pembobotan

Pemeriksaan MRI Leher pada kasus karsinoma nasofaring di Instalasi Radiologi Rumah Sakit Ken Saras Kabupaten Semarang menggunakan 15 sekuen yaitu : T1 TSE multi planar (koronal, axial dan sagital), T2 TSE multi planar, T2 TSE Fat Saturation multi planar dan setelah pemasukan media kontras menggunakan sekuen T1 TSE multi planar di tambah sekuen T1 TSE Fat Saturation multi planar, sehingga waktu Scanning menjadi Sangat lama. Hal ini menyebabkan pasien tidak nyaman dan bisa menimbulkan motion artefact.

Menurut penulis, seharusnya Pemilihan sekuen dan pembobotan disesuaikan dengan kebutuhan klinis, sehingga tidak semua sekuen digunakan. Misal untuk pasien yang tidak kooperatif pemakaian sekuen setelah pemasukan media kontras cukup menggunakan sekuen T1 TSE axial dan sagital serta T1 TSE Fat Saturation axial dan sagital. Menurut responden 3, Pemeriksaan MRI leher pada kasus karsinoma nasofaring bertujuan untuk menentukan stadium dari karsinoma nasofaring, dan stadium dari karsinoma nasofaring sudah bisa di nilai dari potongan axial dan sagital.

5) Slice Thickness dan interslice Gap

Pemilihan slice thickness $3 \mathrm{~mm}$ untuk irisan coronal dan sagital serta $2 \mathrm{~mm}$ untuk irisan axial sudah sesuai dengan protap dan sudah memadai.

6) FOV

Pemilihan FOV 360-420 mm sudah tercover dan SNR yang dihasilkan cukup.

7) Matrix

Pemilihan matrix yang digunakan sesuai kebutuhan sehingga dihasilkan resolusi yang maksimal sesuai kemampuan alat.

8) Center Point

Untuk menentukan center point pada pemeriksaan MRI Leher dengan kasus karsinoma nasofaring yaitu pada pertengahan leher.

Alasan pemeriksaan MRI Leher pada kasus karsinoma nasofaring di Instalasi Radiologi Rumah Sakit Ken Saras Semarang menggunakan penambahan sekuen T1 TSE Fat Saturation setelah pemberian media kontras.

Pemeriksaan MRI Leher pada kasus karsinoma nasofaring di instalasi Radiologi Rumah Sakit Ken Saras setelah pemasukan media kontras di tambahkan sekuens T1 TSE Fat Saturation (Suppresi Lemak) pada potongan axial, coronal, dan sagital. Sekuens ini merupakan protokol tambahan untuk pemeriksaan MRI Leher pada kasus karsinoma nasofaring di RS Ken Saras Kabupaten Semarang.

Penggunaan sekuens T1 Fat Saturation berfungsi untuk mengetahui kondisi dari tumor tersebut sebagai evaluasi post kemoterapi atau radioterapi. Dengan ditambahkannya sekuen T1 TSE Fat Sauration, batas tumor dengan daerah sekitarnya lebih tegas, karena daerah nasofaring juga banyak dikelilingi dengan lemak maka pemberian Fat Saturation ini berguna untuk menekan lemak disekitarnya sehingga gambaran lemak 
akan tampak hitam dan gambaran media kontras yang diserap oleh massa diharapkan akan lebih enhance. Penggunaan sekuen T1 TSE Fat Saturation juga berfungsi untuk menampakan kelainan atau massa pada limfa. Limfa yang normal pada sekuen T1 TSE Fat Saturation tidak akan terlihat karena tersupresi, hal ini di sebabkan karena limfa adalah lemak, tetapi jika ada kelainan/maligna pada limfa, misal limfadenopati maka dia akan terlihat lebih enhance pada sekuen T1 TSE Fat Saturation dengan media kontras.

Menurut dokter radiolog, penggunaan sekuen T1 TSE Fat Saturation pada potongan axial, coronal dan sagital post media kontras pada pemeriksaan MRI Leher pada kasus karsinoma nasofaring adalah karena gambaran tumor akan dibandingkan antara T1 TSE pre dan T1 TSE post kontras. Jika sebelum dikontras massa tampak isodense pada pembobotan T1 TSE, maka diharapkan akan tampak enhance pada T1 TSE post kontras. Agar massa lebih enhance dibandingkan dengan lemak disekitarnya maka post kontrasnya ditambahkan fat saturation, supaya lemak disekitarnya tampak hitam dan massa tampak putih sehingga tidak meragukan lagi gambarannya. Dan biasanya sekuens T1 TSE Fat Saturation ini digunakan apabila karakteristik dari karsinoma banyak mengandung lemak atau berada didaerah sekitar lemak.

Apabila hanya menggunakan sekuens T1 TSE saja pada saat pemeriksaan MRI Leher pada kasus karsinoma nasofaring post injeksi media kontras, batas tepi tumor akan terlihat kurang jelas dan akan susah dibedakan dengan lemak atau soft tissue daerah sekitar.

Menurut Razek (2012), sekuens untuk post kontras menggunakan T1 (dengan dan tanpa Fat Saturation). Dengan T1 TSE Fat Saturation, batas antara massa dengan jaringan di sekitarnya akan tampak dengan jelas sehingga sekuens ini digunakan untuk mendeteksi sejauh mana perluasan dari tumor tersebut, baik perluasannya pada perineural, atau perluasan tumor ke intracranial.

Menurut penulis penambahan sekuen T1 TSE Fat Saturation setelah pemasukan media kontras pada pemeriksaan MRI Leher pada kasus karsinoma nasofaring sudah tepat karena organ-organ di sekitar nasofaring kebanyakan lemak sehingga dengan penambahan Fat Saturation lemak-lemak di sekitar nasofaring akan tersupresi dan akan tampak hitam sedangkan gambaran media kontras yang diserap oleh massa diharapkan akan lebih enhance, sehingga memperjelas batas antara massa dengan jaringan di sekitarnya. Selain itu penambahan sekuen T1 TSE Fat Saturation pada pemeriksaan MRI Leher juga bisa memperjelas kelainan kelenjar limfa di leher. Pada sekuen T1 TSE Fat Saturation kelenjar limfa normal akan tersupresi sehingga akan tampak hitam, sedangkan kelenjar limfa yang ada kelainanya, misalnya limfadenopati akan tampak enhance.

Selain keuntungan keuntungan di atas penambahan sekuen T1 TSE Fat Saturation juga memiliki kekurangan yaitu kita tidak dapat menilai bone marrow (sumsum tulang) serta vaskuler-vaskuler. Hal ini di sebabkan karena pada sekuen T1 TSE Fat Saturation gambaran bone marrow (sumsum tulang) dan vaskulervaskuler akan tampak hipointens/hitam. Tapi hal itu tidak begitu menjadi masalah karena kita bisa menilai bone marrow (sumsum tulang) dan vaskuler-vaskuler pada sekuen yang lain yang tidak menggunakan Fat Saturation.

Alasan pemeriksaan MRI Leher pada kasus karsinoma nasofaring di Instalasi Radiologi Rumah Sakit Ken Saras Kabupaten semarang pada irisan Axial Menggunakan slice thickness $2 \mathrm{~mm}$.

Pemeriksaan MRI Leher pada kasus karsinoma nasofaring di Instalasi Radiologi Rumah Sakit Ken Saras Semarang menggunakan menggunakan slice thickness 2 $\mathrm{mm}$ pada irisan axial. Menurut dokter radiolog, karena organ-organ di nasofaring itu kecil-kecil, sehingga di harapkan dengan penggunaan tebal irisan yang tipis tidak ada kelainan yang terlewatkan. Selain itu penggunaan tebal irisan $2 \mathrm{~mm}$ pada irisan axial juga bermanfaat untuk melihat perluasan stadium di daerah sekitar nasofaring.

Menurut Razek (2012), dengan pemakaian slice thickness $3 \mathrm{~mm}$ maka kelainan-kelainan pada organorgan yang kecil di sekitar nasofaring akan terlihat, sehingga dapat digunakan untuk mendeteksi sejauh mana perluasan dari tumor tersebut, baik perluasannya pada perineural, atau perluasan tumor ke intracranial.

Menurut penulis, pemakaian slice thickness $2 \mathrm{~mm}$ pada irisan axial pada Pemeriksaan MRI Leher pada kasus karsinoma nasofaring di Instalasi Radiologi Rumah Sakit Ken Saras Semarang sudah tepat, karena dengan irisan tipis maka nodul-nodul kecil serta kelainan-kelainan yang masih kecil pada daerah asofaring akan dapat di perlihatkan. Selain itu dengan irisan yang tipis maka musculus-musculus yang tipis pada leher serta percabangan vaskuler yang kecil di leher dapat di nilai sehingga dapat di gunakan untuk mengetahui tingkat stadium dari karsinoma nasofaring tersebut.

Pemakaian slice thickness $2 \mathrm{~mm}$ juga memiliki kekurangan, yaitu waktu scaning yang akan menjadi lebih lama. Menurut Westbrook dan kaut (2011), pemakaian tebal irisan/slice thickness yang tipis akan menghasilkan resolusi yang yang baik, namun pada luas obyek yang sama(FOV) akan membutuhkan waktu scaning yang lebih lama. Hal ini dapat di gambarkan misal lebar obyek yang akan di periksa sebesar $12 \mathrm{~mm}$, maka dengan slice thickness $3 \mathrm{~mm}$ akan menghasilkan 4 gambar sedangkan jika menggunakan slice thickness 2 mm akan menghasilkan 6 gambar. Karena slice thickness $2 \mathrm{~mm}$ menghasilkan gambar lebih banyak dari tebal irisan $3 \mathrm{~mm}$, maka otomatis waktu scanning dengan slice thickness $2 \mathrm{~mm}$ juga akan menjadi lebih lama.

\section{Simpulan}

Prosedur pemeriksaan MRI Leher pada kasus karsinoma nasofaring di Instalasi Radiologi RS Ken Saras Kabupaten Semarang memerlukan persiapan khusus yaitu pasien diharuskan melengkapi dan menandatangani inform consent, pasien diharuskan puasa makan selama 4-5 jam sebelum pemeriksaan, serta 
cek laboratorium ureum dan creatinin. Pada pre kontras menggunakan sekuens T2 TSE, T1 TSE, T2 TSE FS Coronal, Sagital dan Axial, sedangkan pada post kontras menggunakan sekuens TI TSE Coronal, Sagital dan Axial di tambah T1 TSE FS Coronal, Sagital dan Axial.

Alasan pemeriksaan MRI Leher pada kasus karsinoma nasofaring menggunakan penambahan T1 Fat Saturation setelah pemasukan media kontras adalah untuk memperjelas batas tumor dengan jaringan di sekitarnya. Selain itu dengan penambahan sekuen T1 TSE Fat Saturation setelah pemasukan media kontras juga akan memperjelas jika ada gambaran limfadenopati.

Alasan pemeriksaan MRI Leher pada kasus karsinoma nasofaring pada irisan axial menggunakan slice thickness $2 \mathrm{~mm}$ axial adalah agar kelainankelainan/nodul-nodul kecil pada daerah nasofaring dapat di perlihatkan. Selain itu penggunaan slice thickness 2 $\mathrm{mm}$ pada irisan axial juga bermanfaat untuk melihat perluasan stadium di daerah sekitar nasofaring.

\section{Daftar Pustaka}

Asroel, Harry A, 2002, Penatalaksanaan Radioterapi Pada Karsinoma Nasofaring. Diakses tanggal 14 Januari 2018: http://library.usu.ac.id/download/fk/ththary2.pdf

Ballenger JJ. 1994, Aplikasi Klinis Anatomi dan Fisiologi Hidung dan Sinus Paranasal. Dalam : Penyakit Telinga Hidung Telinga Tenggorok Kepala dan leher, Edisi ke13, Binarupa Aksara : Jakarta

Bushberg TT, 2011, The Essentiae Physics of Medical Emaging Third Edition, Williams Wilkins : Philadelphia.

Cameron, Ian, 2009, Technique of Fat Suppression, Diakses tanggal $14 \quad$ Januari 2018, http://cds.ismrm.org/protected/09MProceedings/files/ Tues $\% 20 \mathrm{C}$ Cameron.pdf.

Elmaoglu M,Celik A, 2012, MRI Handook,MR Physics,Patient Positioning and Protocols, Springer : New York.

Faiza S, Rahman S, Asri A, Karakteristik Klinis dan Patologis Karsinoma Nasofaring di Bagian THT- KL RSUP Dr.M.Djamil Padang, Diakses tanggal 12 Januari 2018, http://jurnal.fk.unand.ac.id/index.php/jka/article/view/ $\underline{450}$

George R, J. Dela Cruz, R. Singh, dan Fran Han, 2014, MRI Of Nasofaring. www.mrimaster.com. Diakses pada tanggal 22 Mei 2016.

Kartawiguna, Daniel, 2015, Tomografi Resonansi Magnetik Inti, Teori Dasar, Pembentukan Gambar dan Instrumentasi Perangkat Kerasnya, Graha Ilmu, Jogjakarta.

Klefer Berthold, Wilhelm Horger, 2011, Fat Suppression Techniques-a Short Overview, Diakses tanggal 16 Januari 2018 https://static.healthcare.siemens.com/siemens hwem hwem ssxa websitesroot/wcm/idc/groups/public/@global/@imaging/@mri /documents/download/mday/mju2/ edisp/mri 46 hor ger-01203110.pdf

Kuperman, Vadim, 2000. Magnetic Resonance Imaging Physical Principles and Applications. Academic Press, A Harcourt Science and Technology Company : New York.

Kurniawan P, Yusuf M, 2014, Proses Metastasis pada Keganasan Kepala dan Leher, Jurnal THT - KL, Vol. 7, No. 1. Diakses tanggal 14 Januari 2018 journal.unair.ac.id/download-fullpapersthtkl8acd34b0212full.pdf

Marlinda, Soehartati G, 2017, Kanker Nasofaring, Diakses tanggal $14 \quad$ Januari 2018 kanker.kemkes.go.id/guidelines/PNPKKNF.pdf

Moeller and Reif, 2007. Atlas of Sectional Anatomy, Computer Tomography and Magnetic Resonance Imaging, Thiem Stuttgart : New York.

Moeller dan Reif, 2003. MRI Parameters And Posotioning. Thiem Stuttgart : New York.

Nurul A dan Dwi A, 2017. Instrumentasi pada Magnetic Resonance Imaging, Diakses tanggal 20 Mei 2018, http://dwi-arinivokasi16.web.unair.ac.id/artikel.html

Razek, Ahmed Abdel Khalek Abdel dan Ann King. 2011. MRI and CT of Nasopharyngeal Carcinoma, American Journal, Diakses pada tanggal 22 Januari 2018.

Sudiono J, Irma H, 2013, DNA Epstein-Barr virus (EBV) sebagai biomaker diagnosis karsinoma nasofaring, Jurnal Unair, Diakses pada tanggal 22 Januari 2018. https://e-journal.unair.ac.id/MKG/article/download

Westbrook, C, dan Kaunt, C., 2011, MRI in Practise, Blackwell Science Ltd : United Kingdom.

Woodward, Peggy ang William, W. Arrison, 2001, MRI Optimization, a hand on approach, McGraw-Hill, Co : USA 